Page 43

BACTERIOLOGICAL NOMENCLATURE AND TAXONOMY

CHLOROBACTERIUM, GUILLEBEAU 1890 VS, CHLOROBACTERIUM
LAUTERBORN 1915 , AND

THE STATUS OF CHLOROBACTERIACEAE LAUTERBORN 1913

PRELIMINARY STATEMENT FILE NO. 8

The Editorial Board has prepared the following statement for the consideration of the members of the Judicial Commision, and in order to secure a preliminary ballot fefore a formal Opinion is prepared for final approval. The Editoriai Board will be pleased to receive comments and criticisms from any person interested.

CHLOROBACIERTUR CUI Liebeau (1) 1890 was proposed in the combined generic specific description of a new species chlotoba cum Lacts Guillebeau 1890 The au thor first (p 32) described this organism in a key to the several species of bacteria associated with bovine mastitis He states that it is rod shaped, that it ixquefies gelatin, and that the 1iquid gelatin becomes an in tense green when shaken Later (p 4i) additional characters are enumerated. The cells are $1 \times 3 \beta$ and very motile The lorganism grows well in broth and produces a pellicle. Agar is colored green by the third day there is good growth on potato which becomes green in two days and in seven days dark green to black No acid is produced in sugat media. The

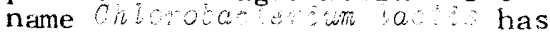
not been adopted in the litera ture nor is there evidence that Guillebeau s organism has been subsequently studied or recognized so far as search of the literature has revealed. No cuiture has been located. Even though Guillebeau did not record the distribution of the flagel la the description would seem to in dicate tia Pseudumotal ae wo nosa (Schroeter) Migula 1900 or some closely rel ated species (I) Guillebeau, Alfred Studien uber Milchfehler und Euterentzundungen bei Rinder und Ziegen 1 Ueber Ursachen der Euterentzundung: Landw Jahrbuch des Schweiz त. 2744
Enlows (1)(1920p. 27) stated Chrorobac terim lacits Guille beau 1890 to be the type species (monotypy)

Chiorocarteraceae Lauterborn (2) 1913 ( $F .99$ )(with the spel1 ing Chiono was pro posed as a tamily name to in clude five genera of bacteria in which the cells contained a yellow green pigment termed bac teriochlorin The five included genera were chloroh omatism, Felodityor. Sehmialea. Fe logloea and Feloch omatium. Later (1915) he (3) again describec Ch 30 oode? acae with the speil ingChiorobakitriaceen He also described a new genus chiono ca. is wa Laterborn 1915 with a single species Ch 0 o voa synoto wh Lauterborn 1915. Van Niel ( 1948 p 872$)(4)$ iisted

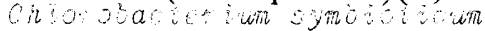
Lauterborn as the type species

(1) Enlows EIlaM A The gen eric names of bacteria Hygienic Laboratory Bull 121. United States Public Health Service. Treasury Dept U S A 920. (2) Lauterborn Robert Zur Kenntnis einiger sapropelischer Schizomyceten. Allg Bot Zeitschrift. 19 99 100 1973 : (3) Lauterborn Robert Die sapropelische Lebewelt Verhand1 $d$, Naturhistor Medizin. Vereins zu Heidelberg. 13425 . 1915

(4), van Niel, C B. Family III Ch bucbacteriaceac Geitler and Pascher in Breed Robert S. E G D. Murray and A Parker Hitchens Bergey s Manual of Determinative Bacteriology. VI Ed. 872 84? 


\section{INTERNATIONAL BULIET IN}

This organism is described as growing symbiotically with certain protozoz

Evidently Chioroba ite ium Lauterborn 1915 is a later hon nym of Chioroba terum Guille beau 1890

Chlorobat teraceae Lauterborn

1913 was pubilished as a family name before the publication of the gerteric name Chio\%obal E : U Lauterborn 1915

Tiue generic name Peudonomis Migula 1895 may bc regardcd ac a Sater synonym of $C h$ hobat Guillebeau tecause of the proba ble ideritity of the type species

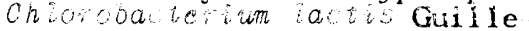
beau 1890 with PSE wamonas aerw. gincea (Schrcier) Mieula 1900 Psevdonorias pyougared (Gessano) (Migula 18G5) the type species of the genus tscudominas vivgula

by subsequent desigration

(Buchanan 1918). (I;

Hec legitimacy of Psewamonos

Niguia $18 \% 5$ mey therefore te. open to question. The substi tution of Chio:00acos thit Guiliebeau 1890 for Psewdomonas Nigula 1894 wouló be a source of ercat confusion and misunder standing:

chlorobacteriareae was recog riced by Geilier and Faselute (1525) without cesignation of the anthor ( 2 ), anc with tive recommendacion tirat 1 it be re tlaced by Crinochloridinat. However Chlorobacteriareac cleariy has pricrity Eurther more Cyanodilotidinat is not in tite forn of a family name

(1) Migula, Wystom der Bakterien 2 , 884 9900 Mígú $W$ Sohizomycetes in Engler and Frant 1, Die Natur. Ijcher Pflanzenfamilion 1 . 1 . 29 895. Buchanan If Etudies in the Nomenclature and class. ification of the bacterie $Y$ Subgrous and genera of the Ba ta tac Jour Ract 348 3818

(2) Geitler $L$ and A. Pascher

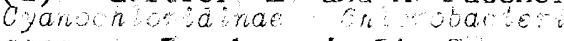
a eae in Pascher A rie Sirswas serflora Deutschlands Oster reich und der Schweiz Heft 12 451,825
Chtorobacte taece is ascribed by van Niel ( 1948 ) to Geitler and Pascher. (1)

Would stability in bacterio lofical nomenclature be advanced and confusion avoided by is suarice of an Opinion by the Judicial Commission cortaining one or more of the following provisions?

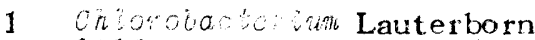
1915 shall be conserved and placed in the list of Eeriera cons aráa.

2 Chbugoa te wim Gilie beau 1890 shail be re jected and $p$ Jaced in the 1 ist of gencra ejulerio

3 Chto ouahtrim Lanterborn IgI5 shall be designates as the type genus of the family chlorboat be bede Lautcriotn $1013 \mathrm{~cm} 195$

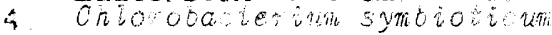
I:auterbori igls is the type srecies of the genus Chlorobaser ium Leuterborn 1915

5. Chborobacterim laits Gijliebeau 1890 sinal be rejected and placed in the list of nonina specifieo. reyisterac.

6. Chlorobar berianeae Lander born $1913 \mathrm{~cm}$ igis shail be conserver and placed in list of fanthae conse? uanation

(1) loc cil p. 869 